\title{
A REPRESENTAÇÃO DO TRABALHADOR EM TEXTOS DRAMÁTICOS LONDRINENSES
}

\author{
Abílio Aparecido Francisco Júnior (Letras, UEL) \\ Diana Kátia Alves de Araújo (Letras, UEL - Bolsista IC CNPq) \\ Sonia Pascolati (LET, CLCH, Coordenadora do Projeto)
}

\section{RESUMO}

A análise do texto literário apoia-se em, pelo menos, duas dimensões: textual e contextual. Esta última contempla intersecções entre a produção do objeto artístico e a sociedade em que ele é produzido. Esses são os pressupostos que guiam nossa análise dos textos dramáticos Tempos de greve (1978), de Domingos Pellegrini, e $A$ constituinte e o trabalhador (1985), de Nitis Jacon, ambos escritores londrinenses em cujas obras ecoam aspectos sociais e políticos de seu tempo, mais precisamente, dos anos finais da ditadura militar e processo de redemocratização nacional. No âmbito temático, os textos tratam do mundo do trabalho, tema que responde a questões imediatas da sociedade brasileira das décadas de 1970 e 1980, mas também é herança do teatro político praticado no Brasil por Gianfrancesco Guarnieri, Dias Gomes, Plínio Marcos e Augusto Boal, dentre outros. Por sua vez, esse teatro político brasileiro mantém diálogo formal com as propostas estéticas do teatro épico brechtiano, cujos recursos de fragmentação da ação e efeito de distanciamento, por exemplo, estão presentes nas peças analisadas. São esses os aspectos abordados neste trabalho ${ }^{1}$ que faz parte das pesquisas do projeto "Contribuições para a historiografia da dramaturgia e do teatro londrinenses".

Palavras-chave: dramaturgia londrinense; teatro político; mundo do trabalho.

\section{INTRODUÇÃO}

A situação precária dos trabalhadores durante as décadas de 1960, 1970 e 1980 é base para a produção dos dois textos dramáticos analisados neste artigo: Tempos de greve, de Domingos Pellegrini (1978) e A Constituinte e o trabalhador, de Nitis Jacon (1985). Ambos os textos são inéditos e foram recolhidos e analisados no âmbito do projeto "Contribuições para a historiografia da dramaturgia e do teatro londrinenses", em desenvolvimento desde 2013 na Universidade Estadual de Londrina. Dentre os objetivos do projeto, está a recolha de textos inéditos esquecidos em gavetas e arquivos, sua digitalização e estudo.

Domingos Pellegrini Júnior (1949- ) é um dos expoentes da literatura londrinense, muito conhecido por seus romances, em especial Terra vermelha (1998), e pela produção literária dirigida aos jovens, com vários títulos populares entre os leitores. Porém, sua dramaturgia permanece praticamente inédita e desconhecida. $\mathrm{O}$ autor possui um texto dramático publicado em coletânea do Prêmio Funarte de Dramaturgia - 2003, representando a região Sul do Brasil, concurso no qual alcançou segundo lugar com a peça $A$ morte do coitado e também uma publicação individual

\footnotetext{
${ }^{1}$ Em razão do limite de 12 páginas para esta publicação, não foi possível abordar todos os aspectos propostos.
} 


\section{SEMINÁRIO DE PESQUISA EM CIÊNCIAS HUMANAS - SEPECH \\ Humanidades, Estado e desafios didático-científicos \\ Londrina, 27 a 29 de julho de 2016}

intitulada Família composta (2006), apoiada e financiada pela Ministério da Educação do Brasil.

Nitis Jacon de Araújo Moreira nasceu na cidade de Lençóis Paulista (SP), em 1935. Em 1960, mudou-se para Curitiba e mais tarde para Arapongas, norte do Paraná. É fundadora do GRUTA, Grupo Teatral de Arapongas e, em Londrina, dirigiu o grupo Núcleo, formado a partir do Festival Universitário de Teatro de Londrina cuja primeira edição é de 1968. Além disso, dirigiu o PROTEU (Projeto Experimental de Teatro Universitário), fundado dez anos depois e responsável pela criação e encenação do texto analisado neste artigo.

Em 1964, inicia-se um dos períodos mais tenebrosos para a história do Brasil, a Ditadura Militar. Tal ação tinha como características principais a repressão aos movimentos sociais e as manifestações de oposição ao governo; a cassação de direitos políticos de opositores; a censura aos meios de comunicação e aos artistas; implantação do bipartidarismo e o uso de métodos violentos, incluindo tortura contra os opositores ao regime. É nesse contexto que Domingos Pellegrini escreveu Tempos de greve, tendo como base a situação trabalhista e reivindicações de classes de trabalhadores.

Já em 1985, após a deflagração do movimento "Diretas Já" (1983-1984), é possível perceber certo otimismo, principalmente em razão da vitória de Tancredo Neves, em 1985, ano da primeira apresentação da peça de Nitis Jacon, A Constituinte $e$ o trabalhador, expondo, como o próprio título já diz, a discussão sobre a reformulação da Constituição após o regime ditatorial. Tal iniciativa apontava novas perspectivas para os trabalhadores que, esperançosos, apostavam em um "novo Brasil" que surgiria da luta conta a opressão.

Dessa forma, é essencial perceber como os dois textos dramáticos dialogam, mesmo sendo de diferentes décadas. Enquanto grupos de trabalhadores buscam uma forma de combater a opressão em um, outros grupos apresentam novas propostas, em reuniões similares, procurando estabelecer uma nova ordem para um futuro com o qual eles poderiam sonhar.

\section{O CONCEITO DE TRABALHO E ALGUNS DETERMINANTES HISTÓRICOS}

Já em sua origem, a palavra "trabalho" é controversa, pois deriva do latim tripalium, "um instrumento feito de três paus aguçados, algumas vezes ainda munidos de pontas de ferro, no qual os agricultores bateriam o trigo, as espigas de milho, o linho, para rasgá-los e esfiapá-los" (ALBORNOZ, 1986, p. 10). Porém, segundo Albornoz (1986), a maioria dos dicionários por ela pesquisados relacionam o trabalho a esse objeto por conta de seu uso na tortura dos trabalhadores, que poderia ter sido a ideia inicial ou ter assim se configurado com o passar do tempo.

Ao diferenciar o trabalho humano do animal, Albornoz (1986, p. 12) afirma que "algo que distingue o trabalho humano do esforço dos animais [...] é que no trabalho do homem há liberdade", o que remete à questão principal discutida neste artigo: qual a representação do trabalho e do trabalhador em determinados momentos históricos? Partindo da diferenciação feita por Albornoz (1986) entre trabalho animal e humano é possível levantar questões que podem ser discutidas a partir da visão dos dois textos dramáticos aqui analisados, tais como: No trabalho do homem há, de fato, liberdade, 


\title{
XI SEMINÁRIO DE PESQUISA EM CIÊNCIAS HUMANAS - SEPECH \\ Humanidades, Estado e desafios didático-científicos \\ Londrina, 27 a 29 de julho de 2016
}

embora não seja reconhecido, na época em questão, o direito de greve? De que liberdade se trata a do mundo do trabalho quando o trabalhador está agrilhoado pela exploração de sua força de trabalho?

Aline dos Santos Laner (2005, p. 116-117), localiza a origem do trabalho no Brasil no contexto escravagista, o que, em certa medida, justifica as situações de exploração representadas nos textos aqui estudados. Segundo ela, é possível afirmar

\begin{abstract}
que o trabalhador brasileiro foi diretamente influenciado pela experiência da escravidão. Prova disso seriam as condições de trabalho enfrentadas pelos primeiros trabalhadores livres. Explica-se tal influência, ainda, através do fato de, entre final do século XIX e início do século XX, ter sido comum o pagamento de salários somente aos mestres e contramestres, enquanto os demais funcionários recebiam somente alimentação, uniforme e o pagamento de um bônus no final do ano. Ainda, neste contexto, a escravidão e a miséria guiaram as práticas de recrutamento e treinamento, baseadas na crença de que os trabalhadores eram "dóceis, ignorantes e carentes de orientação".
\end{abstract}

Principiando por esse conceito, é possível depreender que, além dessa herança escravagista impregnada em nossa concepção de trabalho, o crescimento urbano desordenado ainda alimentou preconceitos com a classe trabalhadora brasileira, tais como o desamor pelo trabalho, a preferência pelo vício, pelo ócio e pela violência (LANER, 2005).

\section{O MUNDO DO TRABALHO EM TEMPOS DE GREVE}

Tempos de greve é um "texto para teatro", segundo indicação de próprio punho de Domingos Pellegrini em datiloscrito datado de setembro de 1978. A estrutura do texto é propositadamente fragmentada com o objetivo de apresentar situações em que a figura do trabalhador, as circunstâncias do trabalho e a situação de greve ocupam a cena, provocando reflexões sobre o contexto em que a peça é escrita - período da ditadura militar -, mas especialmente sobre quaisquer outros contextos em que haja condições histórico, político e sociais semelhantes, como deseja o autor: "O texto deve ser encarado como pretexto para acréscimos e adaptações que relacionem a encenação diretamente com as greves do momento ou com as tradições e experiências grevistas da comunidade a que a apresentação se dirija" (PELLEGRINI, 1978, s.p. ${ }^{2}$ ).

O texto compõe-se de sete cenas que focam situações dramáticas específicas, mas todas interligadas por duas personagens, o Apresentador e o Palhaço. Ambos ocupam a função de comentadores e condutores da ação e dirigem-se claramente ao leitor/espectador, estimulando a reflexão crítica sobre o que é representado. A fragmentação da ação, descontínua e não linear e os efeitos de distanciamento são elementos próprios do teatro épico brechtiano. A feição crítica do texto fica evidente desde os primeiros momentos da ação quando o Apresentador associa o trabalho a uma atividade comum a animais e homens, com a diferença de que o homem é o único

\footnotetext{
${ }^{2}$ A paginação do texto original, datilografado, inicia-se após 2 folhas, uma com título e indicação de gênero e outra com a rubrica inicial.
} 


\section{SEMINÁRIO DE PESQUISA EM CIÊNCIAS HUMANAS - SEPECH \\ Humanidades, Estado e desafios didático-científicos \\ Londrina, 27 a 29 de julho de 2016}

animal que o usa o trabalho alheio como forma de exploração e questiona o receptor acerca da realidade que o cerca: "Mas quem é o chupim do homem a vida toda ${ }^{3}$ ? Cada um pense." (PELLEGRINI, 1978, p. 1).

A primeira cena representa uma assembleia de operários discutindo a adesão ou não à greve, evidenciando a falta de confiança na eficácia da greve, ao mesmo tempo que revelam profunda insatisfação com as condições de trabalho e de sobrevivência cotidiana. A cena dois transporta o receptor para outro espaço-tempo em que se desenrolam cenas simultâneas: de um lado, uma funcionária dos Correios apresentando ao noivo seus argumentos para entrar em greve; na mesa ao lado, os outros dois funcionários do posto dos correios criticando a colega, que julgam indecisa. Para a introdução da terceira cena, nova mudança de tempo e espaço, localizando a ação na casa paroquial de um padre simpático à juventude e às causas operárias e procurado tanto pelos trabalhadores - que pedem uma missa como pretexto para reunir trabalhadores e suas famílias - quanto pelo industrial que pede a benção do padre na inauguração de um restaurante para desestabilizar a greve. A quarta cena transporta o leitor/espectador para uma sala de interrogatório policial no qual uma Moça tenta explicar, em vão, que não é comunista, nunca foi sindicalizada, mas sentiu a necessidade de aderir à greve. Já a quinta situação dramática coloca em cena duas categorias em oposição - patrão e empregados. A oposição das categorias deixa claro o apequenamento do operário diante da simulação de seriedade e relevância do trabalho de gerenciamento da fábrica, desvalorizando o trabalho na linha de produção. A penúltima cena dialoga com a primeira, pois também se trata de uma assembleia, mas agora quem se reúne são os representantes de muitas categorias profissionais e sindicais, reforçando a falta de unidade no movimento trabalhista e revelando os motivos que fragilizam movimentos grevistas, dentre os quais o medo de que a greve acentue a desunião entre as categorias, receio de perder o emprego e ficar marcado como grevista e necessidade de reivindicar outros direitos além de melhoria salarial. A cena de número sete, que fecha a peça, retoma a simultaneidade de ações no palco, ocupado por um grupo de professores em greve e, de outro lado, pelo Governador e seus assessores. Ambos os grupos estão temerosos de não suportar a continuidade da greve, cada qual por suas razões, mas quem acaba cedendo são os professores.

Como se vê nesta breve descrição, todas as situações focam o mundo do trabalho e a ação de trabalhadores em luta por direitos, portanto, apesar da evidente fragmentação, a recorrência temática contribui para o efeito de unidade. Além da representação das angústias e lutas dos trabalhadores, outras faces do mundo do trabalho também são encenadas: a manipulação de patrões, donos dos meios de produção, mascarando dados de faturamento para justificar os baixos salários; as relações entre esses mesmos patrões, a polícia e a imprensa, instituições que protegem os interesses dos industriais em detrimento do trabalhador; a compreensão manipuladora de que a reivindicação de direitos está subordinada a ideais comunistas; a representação de um governo controlador e violento que se apresenta como legítimo representante da democracia.

\footnotetext{
${ }^{3}$ Foi realizada atualização ortográfica na transcrição de trechos do texto dramático e também adotamos itálico para registro das rubricas, recurso indisponível na datilografia, mas usual para indicações cênicas em textos dramáticos.
} 


\section{SEMINÁRIO DE PESQUISA EM CIÊNCIAS HUMANAS - SEPECH \\ Humanidades, Estado e desafios didático-científicos \\ Londrina, 27 a 29 de julho de 2016}

Sobre as representações do trabalho, percebe-se um desencontro entre um discurso de valorização do trabalho como atividade humana, perceptível especialmente na fala do Noivo da funcionária do correio - "Trabalho não é vergonha pra ninguém" (PELLEGRINI, 1978, p. 7) - e do Presidente dos grevistas reunidos em assembleia "ser contra o trabalho é a pior viagem / Afinal, o trabalho enobrece o homem" e a real situação do trabalhador retrata pelo texto e expressa, por exemplo, na réplica de um grevista: "O trabalho enobrece e o descanso também. / Mas como a gente descansa com o salário que tem?" (PELLEGRINI, 1978, p. 4).

A denúncia das condições de trabalho à época é um ponto forte do texto. Em assembleia, o Presidente responde ao grevista que reclama do salário que ele deveria fazer horas extras, portanto, em vez de lutar por valorização do operário, ele deveria permitir exploração ainda maior, afinal, a hora extra se torna mais uma forma de exploração da força de trabalho.

A rotina do trabalhador também é apresentada como forma de assujeitamento ao sistema exploratório, uma espécie de reificação do trabalhador que perde sua humanidade ao ser praticamente assimilado à engrenagem da fábrica, aspecto evidenciado na fala do Palhaço a apresentar uma nova personagem, a Moça da cena quatro:

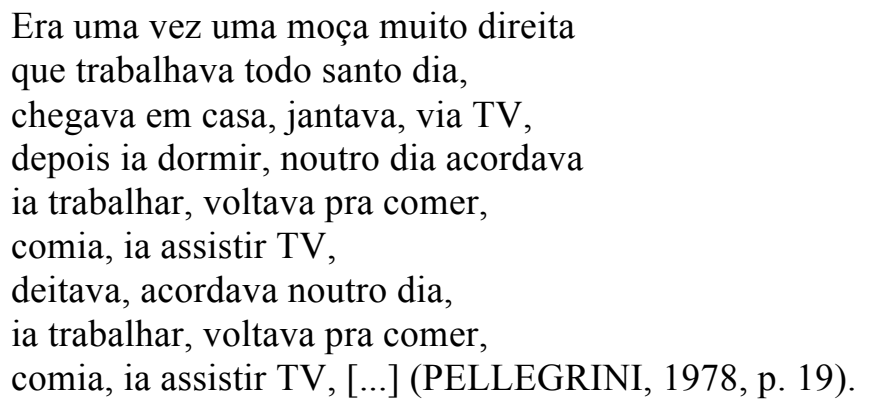

Além de todos esses aspectos, há ainda a relação entre o mundo do trabalho, a realidade do trabalhador e o contexto político nacional de repressão. Em 1978, o país caminhava, embora titubeante, rumo à abertura política, com um governo um pouco menos repressivo. Nessa mesma época, " $43 \%$ dos operários eram sindicalizados". Diante de perdas salariais que chegavam a mais de $30 \%$,

O Sindicato dos Metalúrgicos de São Bernardo e Diadema iniciou uma campanha para correção dos salários. Essa campanha abriu caminho para as grandes greves de 1978 e 1979, que reuniram milhões de trabalhadores [...]. Em 1979, cerca de 3,2 milhões de trabalhadores entraram em greve no país. Houve 27 paralisações de metalúrgicos que abrangeram 958 mil operários; ao mesmo tempo, ocorreram vinte greves de professores que reuniram 766 mil assalariados (FAUSTO, 1999, p. 499-500).

O tratamento dado ao grevista é explicitado particularmente durante o interrogatório da Moça pelo Policial inconformado com o abrandamento da lei, ou melhor, do poder arbitrário da força policial contra o trabalhador. Referindo-se ao escrivão, o Delegado ameaça com empáfia: 


\section{SEMINÁRIO DE PESQUISA EM CIÊNCIAS HUMANAS - SEPECH \\ Humanidades, Estado e desafios didático-científicos \\ Londrina, 27 a 29 de julho de 2016}

POLICIAL - [...] O João Batista é do tempo que grevista era tratado a pancada, não era essa avacalhação de hoje. (Ao Escrivão) A gente já ouviu quantos hoje? Dez? Vinte?

ESCRIVÃO - Com essa, treze.

POLICIAL - Por mim, baixava o cacete em todo mundo, tá entendendo, neguinha? (Coça o saco demoradamente). Tá entendendo? Por mim não tinha nada que ficar fazendo perguntinha não, era no pau (PELLEGRINI, 1978, p. 19).

Portanto, a tônica do texto é o mundo do trabalho, com destaque para as condições de trabalho, as condições e circunstâncias de greve e a relação do trabalhador com instituições como o gerenciamento industrial, a igreja, o governo e a polícia.

\section{A CONSTITUINTE E A ESPERANÇA DE MELHORIA DAS CONDIÇÕES DE TRABALHO}

Em $1^{\circ}$ de maio de 1985 , o Proteu apresentava sua mais nova montagem: $A$ Constituinte e o trabalhador. Com texto de Nitis Jacon (1935- ), a partir do título da peça e a data em que foi encenada, Dia do Trabalhador, instantaneamente cria-se uma ideia do enredo.

Nota-se que o texto é estruturado de forma linear e concentra-se em uma única ação, a reunião de trabalhadores em assembleia. A ruptura da quarta parede ${ }^{4}$ acontece na medida em que não há limites entre palco e plateia, como registra a rubrica inicial:

O espetáculo segue a linha de uma reunião inter-sindical, devendo iniciar-se sem aviso prévio, com a simples entrada dos atores e sua participação inicial na plateia. Apenas o coordenador sobe inicialmente para dar início à reunião. Alguns deverão subir no palco ou ir ao local onde se concentrarão "as lideranças" permanecendo os outros entre o público (jacon, 1985, p. 1).

As personagens, em sua maioria, mesmo pertencendo a esferas sociais distintas, são representadas como pessoas simples que simbolizam diversos tipos de trabalhadores, seja nos espaços urbanos ou rurais. Todos trazem marcas de submissão, do abuso de poder que sofrem perante seus superiores e a exploração, que em algumas vezes esgotava o trabalhador, representada diversas vezes. Para evidenciar a que ponto chegavam as situações de exploração, podemos mencionar a personagem "bêbado" que no decorrer da peça revela o motivo de estar nesta situação: "(da plateia) Pergunta... Pergunta... Eu sô ensacadô... Qué dizê, era né... agora tô encostado faz 3 ano. Caiu um saco de mau jeito... agora tenho acesso..." (JACON, 1895, p. 10). Das personagens que se diferenciam, além dos representantes partidários, que apenas aparecem para citar suas vertentes políticas, se destaca o "Pelego", personagem não só contrária aos trabalhadores mas traidora e delatora das reivindicações trabalhistas. Entretanto, é surpreendida pela perspicácia dos trabalhadores e suas más intenções são afugentadas.

\footnotetext{
${ }^{4}$ Expediente por meio do qual a ilusão dramática é rompida, pois o palco dialoga diretamente com o espectador.
} 


\section{SEMINÁRIO DE PESQUISA EM CIÊNCIAS HUMANAS - SEPECH \\ Humanidades, Estado e desafios didático-científicos \\ Londrina, 27 a 29 de julho de 2016}

A linguagem do texto de Jacon é simples e clara, com reprodução do falar simples e cotidiano, como se os trabalhadores, mesmo com algumas diferenças, se unissem para criarem uma única voz. Os discursos proferidos individualmente funcionam como uma complementação dos desejos de todas classes. Entre os trabalhadores não há quem queira se sobressair, pois todos buscam um objetivo em comum: serem ouvidos pelos dirigentes do país e terem seus direitos assegurados.

O texto dramático foca em uma reunião intersindical entre representantes de alguns sindicatos de trabalhadores para tratar das questões trabalhistas de cada categoria. A proposta é que cada movimento coopere com sugestões, soluções e ideias como contribuição para a futura Constituinte reclamada já nessa época pela população, mas que só seria convocada em novembro de 1985 e cujos trabalhos se iniciaram em fevereiro de 1987 (BRASIL, 1988).

Antes de iniciar a cena, há uma nota explicativa: o texto permite a introdução de novos textos de acordo com o local em que será encenado ou a diversificação do grupo social ao qual é destinado, principalmente pela atuação de um dos personagens denominado "Coordenador", exatamente o mesmo procedimento do texto de Pellegrini. Nota-se que se trata de uma personagem importante para a peça, o que é evidenciado na explicação de sua função: "(O coordenador pode assumir a representação de qualquer sindicato ou associação para permitir colocações mais especificas de acordo com cada plateia) (JACON, 1985, p. 2).

Estão reunidos representantes dos sindicatos dos metalúrgicos, ferroviários, bancários, fiação e tecelagem, trabalhador rural, professores, diaristas e também aparecem personagens em cena sem representação sindical, como o "di menor", a "mulher" e o "bêbado". Tal como o texto analisado anteriormente, categorias profissionais são postas em cena, mais que personagens individualizadas.

A peça se inicia com o chamado do Coordenador que explica os motivos da reunião: tratar da forma como os trabalhadores eram ignorados na política do país, dos direitos que lhes eram negados, das necessidades não supridas e juntar as forças para que suas reivindicações fossem finalmente ouvidas: "- Também, 20 anos sem poder falar... a gente desacostumou..." (JACON, 1985, p. 1). A referência é aos anos de ditadura, durante os quais os movimentos trabalhistas não tinham liberdade plena de organização e manifestações contrárias ao governo eram contidas com violência policial.

Cada representante discorre sobre sua condição de trabalho e assim são levantados os problemas enfrentados pelas categorias. A representante do sindicato da fiação e tecelagem reclama sobre a falta de assistência médica do seu sindicato e do abuso de poder enfrentado com as revistas diárias a seus pertences e corpos. A personagem denominada "Mulher" relata o preconceito enfrentado pelas mulheres em todas as categorias trabalhistas: salários inferiores aos homens mesmo que ambos façam o mesmo serviço e falta de assistência às trabalhadoras que engravidam ou têm filhos, pois muitas são mandadas embora ou nem têm oportunidade de emprego. As empregadas domésticas também apontam os problemas enfrentados como o acúmulo de serviço e os baixos salários, o assédio por parte de alguns patrões, as folgas descontadas, a maioria sem registro em carteira de trabalho e também reclamam da falta de participação dos maridos nas atividades domésticas cotidianas. A personagem "di menor" retrata o abuso que sofre: trabalhar desde criança, muitas vezes no período noturno, para ganhar um salário baixíssimo. O trabalhador rural reclama do trabalho 


\section{SEMINÁRIO DE PESQUISA EM CIÊNCIAS HUMANAS - SEPECH \\ Humanidades, Estado e desafios didático-científicos \\ Londrina, 27 a 29 de julho de 2016}

pesado enfrentado pela família inteira na roça e o pouco retorno financeiro da atividade agrícola. O representante do sindicato dos ensacadores descreve o quanto seu serviço é ingrato: apenas os novos e fortes conseguem trabalho, não há quem resista muito tempo, pois não é tão simples carregar sacos de sessenta quilos na cabeça jogados de uma altura de quase dez metros.

Em determinado ponto do texto, três representantes de partidos políticos aparecem para apresentar suas linhas partidárias: o PC do B, o PCB e o PT. Um representante do sindicato de metalúrgicos interfere nos discursos e reafirma que a reunião proposta desde o início é para os sindicatos se organizarem e aliarem suas forças para serem independentes, tanto de um governo, quanto de algum partido político, pois as interferências partidárias dividiam a classe de trabalhadores e a ideia principal era justamente de união entre as entidades sindicais.

Há uma personagem que sempre aparece com um discurso polido, que ampara a classe dos trabalhadores, entretanto, sua qualificação na peça levanta suspeitas sobre suas intenções, pois é chamado de "Pelego", termo popular durante a era Vargas, utilizado como sinônimo de traidor e aliado do governo e dos patrões contra os interesses dos trabalhadores. No momento em que Pelego discursa sobre as questões sindicais e sobre política, alguns representantes intrometem-se e relatam que a personagem foi nomeada interventor do Ministério do Trabalho no início da Ditadura Militar e inibia a conscientização política nos sindicatos.

Ao final da obra, os trabalhadores questionam se todas estas reivindicações seriam mesmo atendidas e se constariam na Constituição. O Coordenador explica que, de certa forma, os pedidos seriam levados para que fossem contemplados na carta constitucional e cita como exemplo a emenda da constituinte da Lei de Greve ${ }^{5}$ que impede que os trabalhadores lutem para conseguir suas solicitações e era justamente essa nova Constituição que garantiria seus direitos e deveres.

No contexto histórico de produção do texto, 1985 foi de extrema importância, pois se encerrava o ciclo da temida Ditadura Militar que dominara por mais de 20 anos. Vale lembrar que a ditatura não só privou qualquer ato democrático na política brasileira, como também espalhou medo e terror à população: censuras nos meios de comunicação, nos meios culturais e até nas universidades e nas escolas. A brutalidade e a violência evidenciadas pelas torturas e prisões de quem era contra o regime foram algumas das situações absurdas a que os brasileiros tiveram que resistir.

A ordem, e não só política, precisava ser restituída em todo país e as classes dos trabalhadores seguiam na luta pelos seus direitos. Os problemas expostos no texto de Jacon são apenas uma pequena parte da triste realidade que o operariado enfrentava na época. As injustiças pairavam sobre estas classes e não havia nos sindicatos força e amparo para lhes dar assistência.

A obra apresenta diversas formas de exploração registradas ficcionalmente, um retrato do modo como milhares de trabalhadores viviam por todo o Brasil. Percebe-se que não havia preocupação por parte do empregador para com seus empregados. Hoje, os trabalhadores podem contar com o auxílio do judiciário, sistema que prevê assistência para a garantia de direitos trabalhistas, porém, infelizmente, não são todos

\footnotetext{
${ }^{5}$ Em 1967, com a nova Constituição, admite-se o direito de greve, proibindo-o, porém, nos serviços públicos e essenciais (Decreto - Lei 1.632/78). Entendimento semelhante tinha a Emenda Constitucional 01 de 1969. Além dessas limitações, a Lei 6.620/78, estabelecia punição ao incitamento à paralisação de serviços públicos e à cessação coletiva do trabalho pelos funcionários públicos.
} 


\section{SEMINÁRIO DE PESQUISA EM CIÊNCIAS HUMANAS - SEPECH \\ Humanidades, Estado e desafios didático-científicos \\ Londrina, 27 a 29 de julho de 2016}

que conseguem este benefício. Se, atualmente, esses direitos não são facilmente garantidos, há alguns anos essas garantias nem chegavam a ser mencionadas por patrões ou conhecidas pela população, principalmente os mais humildes.

\section{DRAMATURGIA LONDRINENSE E REPRESENTAÇÕES DO TRABALHADOR}

Pela breve apresentação dos textos dramáticos londrinenses, é possível perceber como os dramaturgos estavam sintonizados com o contexto político e econômico do Brasil das décadas de 1970 e 1980. Embora os textos sejam já da fase de abertura política, fica clara a presença de forças repressivas do período ditatorial, representadas particularmente pela presença das personagens Policial, no texto de Pellegrini, e Pelego no de Jacon.

A penúria dos trabalhadores e a exploração da força de trabalho pelos setores produtivos são evidentes em ambos os textos, mas o que chama a atenção é a dificuldade da união dos trabalhadores em torno de causas comuns. A situação política é, evidentemente, um entrave para a organização, como faz questão de sublinhar o Coordenador da assembleia sindical retratada na cena seis de Tempos de greve: "Eu lembro aos companheiros que contra a gente já tem os patrões, a polícia, os políticos; não tem sentido se agredir mutuamente" (PELLEGRINI, 1978, p. 33). Todavia, é a dificuldade de união dos trabalhadores que merece destaque, em oposição à capacidade de organização dos setores empresariais e industriais, como frisa a Canção do Palhaço, inserida como "Adendo" pelo dramaturgo: "Ai ai meu irmão / a união faz a força / por isso não há quem possa / com a classe dos patrões / (breque) A união / a união faz a força / por isso não há quem possa / com a classe dos patrões / Ai meu irmão" (PELLEGRINI, 1978, p. 37A).

Mas também são evidentes as pressões que pesam sobre o trabalhador em sua tentativa de organização. Os líderes são chamados de comunistas, termo empregado pela elite governante para caracterizar o grande inimigo da nação. Os que aderiam a greves sofriam repressão ao próprio movimento de organização, com intimidação por prisão, assim como ameaças de demissão. Vivia-se um clima de repressão muito grande, o que dificultava articulações e resultava numa população acuada e controlada pela mídia que, por sua vez, estava, ao menos em parte, submissa ao governo ou calada por ele. Ambas as obras confirmam a avaliação de Albornoz (1986, p. 76): “a integração dos trabalhadores sempre foi acompanhada de formas de pressão, como a ameaça da perda dos meios de sobrevivência, a distribuição da 'justiça', a polícia, as forças armadas".

Tanto no texto dramático de Nitis Jacon, A Constituinte e o trabalhador, como no de Domingos Pellegrini, Tempos de greve, são apresentadas as dificuldades da organização sindical. Pensando nisso, recorremos às palavras de Hobsbawm (2000, p. 213-214, grifos do autor), sobre as organizações de sindicatos em sua origem, na Inglaterra, no fim da década de 1880. Segundo ele, os sindicatos trabalhistas gerais ainda hoje têm 


\section{SEMINÁRIO DE PESQUISA EM CIÊNCIAS HUMANAS - SEPECH \\ Humanidades, Estado e desafios didático-científicos \\ Londrina, 27 a 29 de julho de 2016}

desempenhado três funções bastante distintas - muitas vezes simultaneamente. Como sindicatos de "classe" eles têm tentado unir todos os trabalhadores contra todos os patrões, geralmente sob inspiração socialista ou revolucionária. Como sindicato de "trabalhadores", eles têm tentado fornecer organização efetiva aos trabalhadores incapazes ou excluídos do sindicalismo de classe ortodoxo. Como sindicatos "residuais", finalmente, eles organizaram qualquer corpo de trabalhadores não-efetivamente abrangidos por outros sindicatos (e alguns que eram): nem a primeira nem a terceira funções exigem qualquer forma especial de organização.

Dessa forma, a partir da definição de Hobsbawm, percebemos como ambos os textos dramáticos representam essas diferentes formas de organização (ou tentativas de), mesmo a terceira que, no texto de Jacon, é caracterizada pela iniciativa de incorporar o trabalho infantil, representado pela personagem "di menor". O desejo é dar voz ao trabalhador que quer ser ouvido e precisa reclamar e confrontar o patrão em busca de melhorias significativas na situação trabalhista.

\section{REFERÊNCIAS}

ALBORNOZ, Suzana. O que é trabalho. São Paulo: Brasiliense, 2000.

BRASIL. Constituição (1988). Constituição da República Federativa do Brasil. Disponível em: <http://www.planalto.gov.br/ccivil_03/constituicao/constituicao.htm>. Acesso em: 11 maio 2016.

FAUSTO, Boris. História do Brasil. São Paulo: Edusp, 1999.

HOBSBAWM, Eric J. Os trabalhadores: estudo sobre a história do operariado. São Paulo: Paz e Terra, 2000.

JACON, Nitis. A Constituinte e o trabalhador. 1985. Texto inédito, datilografado.

LANER, Aline dos Santos. Psicologia e trabalho na história: da apropriação do tempo à busca da felicidade. Ijuí: Ed. Unijuí, 2005.

PELLEGRINI, Domingos. Tempos de greve. 1978. Texto inédito, datilografado. 